\title{
MORPHOGENESIS OF AUJESZKY'S DISEASE VIRUS IN PIG LUNG MACROPHAGE CULTURES
}

\author{
B. ŠMÍD, L. VALÍCEK and *A. SABÓ \\ Veterinary Research Institute, 62132 Brno and *Institute of Virology, Slovak Academy of Sciences, \\ 80939 Bratislava
}

Received August 1, 1980

\begin{abstract}
Šmíd B., L. Valíček, A. Sabó: Morphogenesis of Aujeszky's Disease Virus in Pig Lung Macrophage Cultures. Acta vet. Brno, 59, 1981:.79-87.

A virulent strain of Aujeszky's disease virus replicated in vitro in pig lung macrophages (PLM) from colostrum-deprived piglets aged 14, 23 and 45 days. The infecting dose was $5 \mathrm{PFU} /$ cell. Core-like particles and nucleocapsids were observed in the nucleus 4 and 8 hours after infection, respectively. Single virions in the extracellular space were first observed 10 hours after infection. At later stages of infection the nucleus contained numerous nucleocapsids, frequently arranged in crystalline arrays, and the cytoplasm showed numerous virions both in tubules of the smooth endoplasmic reticulum and in lysosomes. At the same time numerous virions were present also in the extracellular space, but only few of them showed a large amount of electron dense material between the nucleocapsid and the envelope.
\end{abstract}

Aujeszky's disease virus, pig lung macrophages, electron microscopy.

Although electron microscopy is a promising tool for studies on the morphogenesis of herpesviruses in macrophages, little use has been made of approach to date. Johnson (1964) found numerous normal virions in the cytoplasm of macrophages from suckling mice infected with herpes simplex virus type 1 (HSV-1). On the other hand, Stevens and Cook (1971) reported that the cytoplasm of macrophages from HSV-1 infected adult mice contained only solitary virions, while the majority of cells contained capsid without cores.

Of the two herpesviruses found in pigs, namely Aujeszky's disease virus (ADV) and porcine cytomegalovirus (PCMV), only the latter was studied for morphogenesis in macrophages (Valíček and Šmíd 1979). Cultures of pig lung macrophages (PLM) are the most sensitive system for propagation of PCMV (Watt et al. 1973) which replicates in PLM also in vivo (Edington et al. 1976).

The other of the two herpesviruses found in pigs, ADV, affects the nervous system and occasionally also the respiratory tract of infected animals (Baskerville et al. 1972). Most attention to date has been given to the nervous system; a recent study described the latency of ADV also in gasserian ganglia (Sabó and Rajčáni 1976). The respiratory tract, on the other hand, has received little attention in this respect. Although ADV was demonstrated in PLM in vivo by electron microscopy (Baskerville 1972), there is no published information on its replication in PLM in vitro. The question of ADV replication in PLM is relevant in view of the assumption that macrophages play a major role in the pathogenesis of viral infections as an important factor of cell-mediated immunity and possibly also in the persistence of viral infection (Mims 1974; Silverstein 1970; Stevens and Cook 1971; Mogensen 1979). Viewed in this light PLM provide a suitable substrate for studies of the aforementioned subjects.

The object of the present study was to assess the ability of ADV to replicate in PLM in vitro and to investigate its morphogenesis in these cells. 


\section{Materials and Methods}

Virus

A virulent strain of $\mathrm{ADV}$, Plzeň $\mathrm{V} 8 / 73$, was isolated in primary pig kidney cell cultures from pigs involved in an outbreak of Aujeszky's disease. After three passages on pig kidney cell line PK-K a stock suspension with a titre of $1 \times 10^{8} \mathrm{PFU} / \mathrm{ml}$ was obtained and used in the experiment.

\section{Cultures of Pig Lung Macrophages}

Three hysterectomy-derived Large White piglets reared in incubators on a high-caloric semisynthetic diet (Holub 1963) were killed at 14, 23 and 45 days of age to obtain lung macrophages. The cultures of PLM were prepared by a method described in detail in a previous study (S míd et al. 1976). Briefly, cells washed out from the lungs of piglets were centrifuged and resuspended at a concentration $1 \times 10^{6} / \mathrm{ml}$ in Eagle's minimum essential medium supplemented with $25 \%$ calf foetal serum. After incubation for 2 hours, $37^{\circ} \mathrm{C}$, unattached cells and cellular debris were removed by shaking and by a change of medium. The PLM cultures were grown in $50 \mathrm{ml}$ bottles.

\section{Infection of PLM Cultures}

PLM cultures were infected with 5 PFU/cell of ADV strain Plzeň V 8/73 which was adsorbed for 1 hour at $37^{\circ} \mathrm{C}$. The bottles were then washed three times with phosphate buffered saline and supplemented with Eagle's minimum essential medium containing $25 \%$ calf foetal serum.

\section{Electron Microscopy}

PLM cultures were fixed in 1 per cent glutaraldehyde 2, 4, 6, 8, 10, 16 and 21 hours after infection. The fixed cells were scraped from the glass, centrifuged, post-fixed in $1 \% \mathrm{OsO}_{4}$, dehydrated in acetone and embedded in Epon 812-Araldit. The blocks were sectioned on a Tesla BS 490 ultramicrotome and doubly stained with uranyl acetate and lead citrate and examined with a Tesla BS 513 electron microscope.

\section{Results}

Two hours after infection the cytoplasm of PLM was disintegrated and contained destroyed virions and nucleocapsids occurring singly or in clusters, frequently in electron dense lysosomes (Fig. 1). There was also lysis of the nuclear membrane (Fig. 1). Occasionally, complete cell destruction was observed, presumably caused by penetration of a large quantity of virus into the cells (Fig. 2). Four hours after infection the nucleus contained electron dense core-like particles of irregular shape, single or clustered in groups (Fig. 3). Newly formed nucleocapsids in the nucleus were first observed 8 hours after infection; they occurred singly and had cores of varying density (Fig. 4). Nucleocapsids acquired an envelope either in the nucleus by budding from the inner lamella of the nuclear membrane into the perinuclear cisterna (Fig. 5) or in the cytoplasm by budding into tubules of the smooth endoplasmic reticulum (Fig. 6). At later stages of infection the nucleus contained numerous nucleocapsids with cores of varying density, frequently arranged in crystalline arrays (Fig. 7). Occasionally, the nuclear membrane had become reduplicated or even destroyed, and nucleocapsids were released into the cytoplasm (Fig. 8). Newly formed complete virions were first demonstrated in the cytoplasm of PLM ten hours after infection. Sixteen hours after infection numerous virions were present in the cytoplasm either in lysosomes showing varying stages of destruction (Fig. 9) or in tubules of the smooth endoplasmic reticulum (Fig. 10). At the same time numerous virions were seen also in the extracellular space where they arrived via the tubules of the endoplasmic reticulum.

The majority of extracellular virions had a centrally-located nucleocapsid surrounded by an electron lucent halo and showed a unit membrane structure 

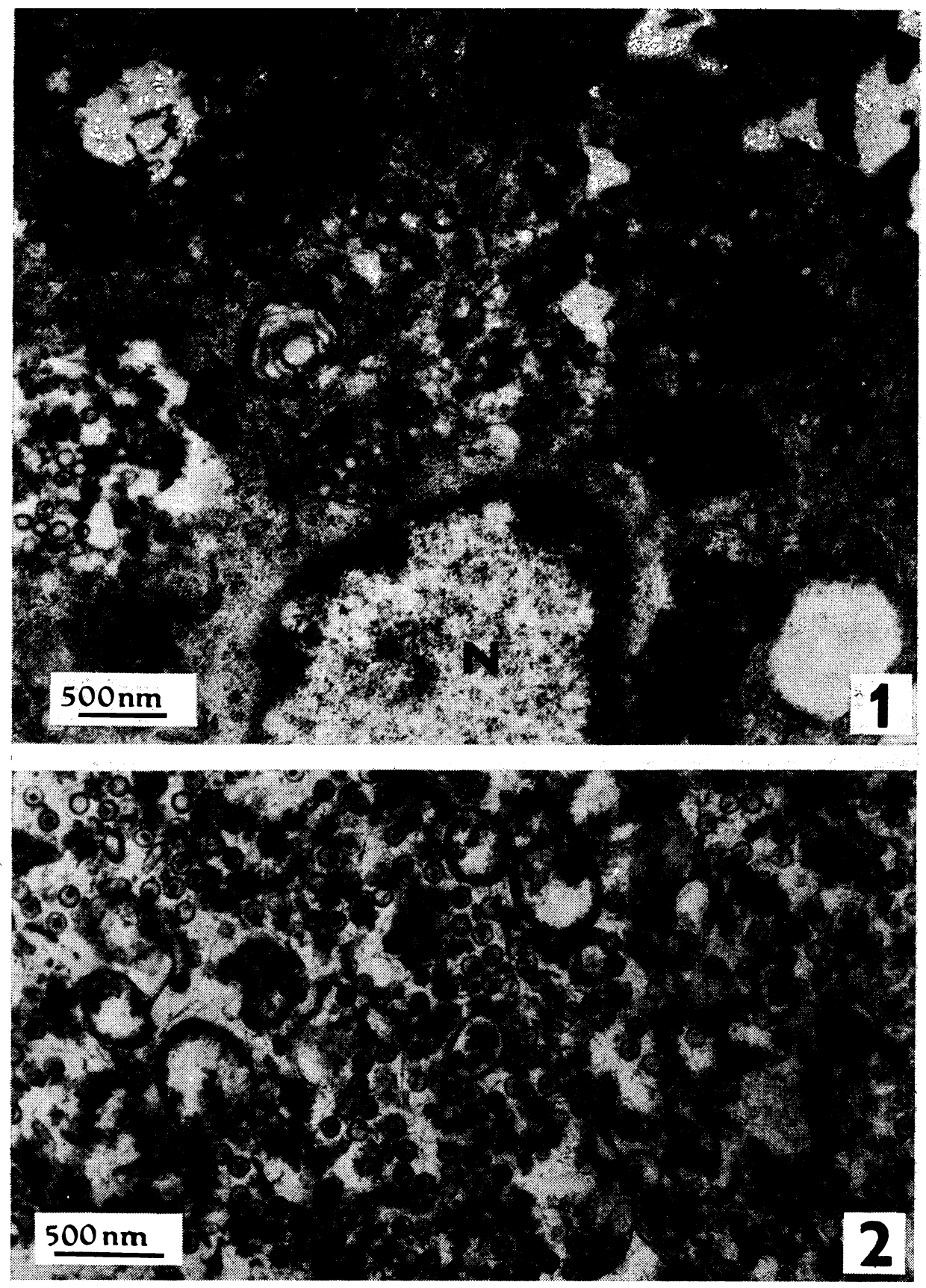

Fig. 1

Numerous nucleocapsids located free or in lysosomes in the disintegrated cytoplasm (C). Lysis of the nuclear membrane (PLM 2 hours after infection).

Fig. 2

Marked destruction of cytoplasmic organelles containing numerous nucleocapsids or empty capsids (PLM 2 hours after infection). 

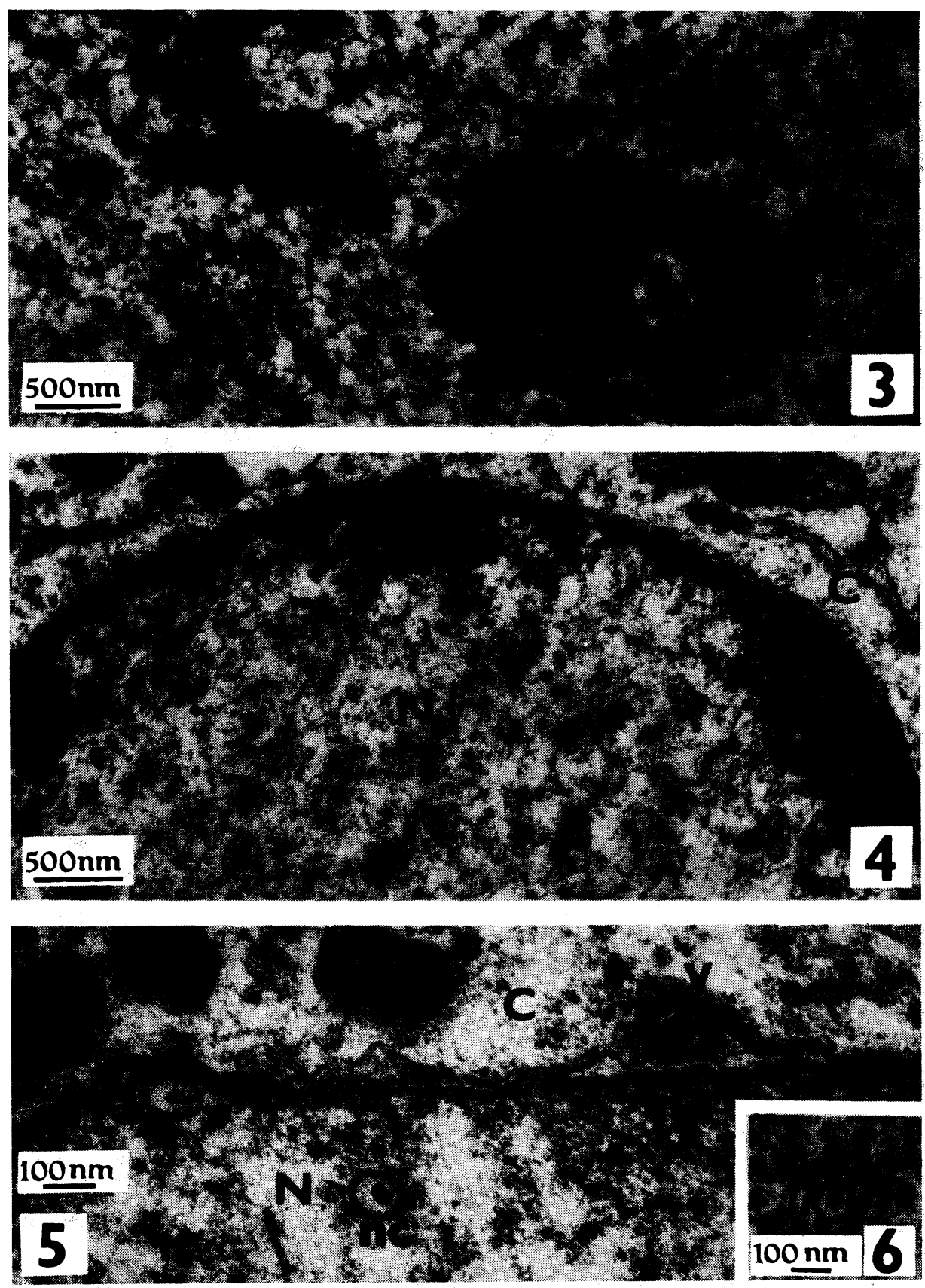

Fig. 3

Clusters (cl) of electron dense core-like particles in the nucleus (N); (PLM 4 hours after infection). Fig. 4

Single nucleocapsids in the nucleus (N); (PLM 8 hours after infection).

Fig. 5

Nucleocapsid (nc) in the nucleus $(\mathrm{N})$ and virion $(\mathrm{V})$ in the perinuclear cisterna after acquisition of an envelope from the inner lamella of the nuclear membrane (PLM 16 hours after infection).

Fig. 6

Nucleocapsid budding into smooth-membraned tubules (PLM 16 hours after infection). 

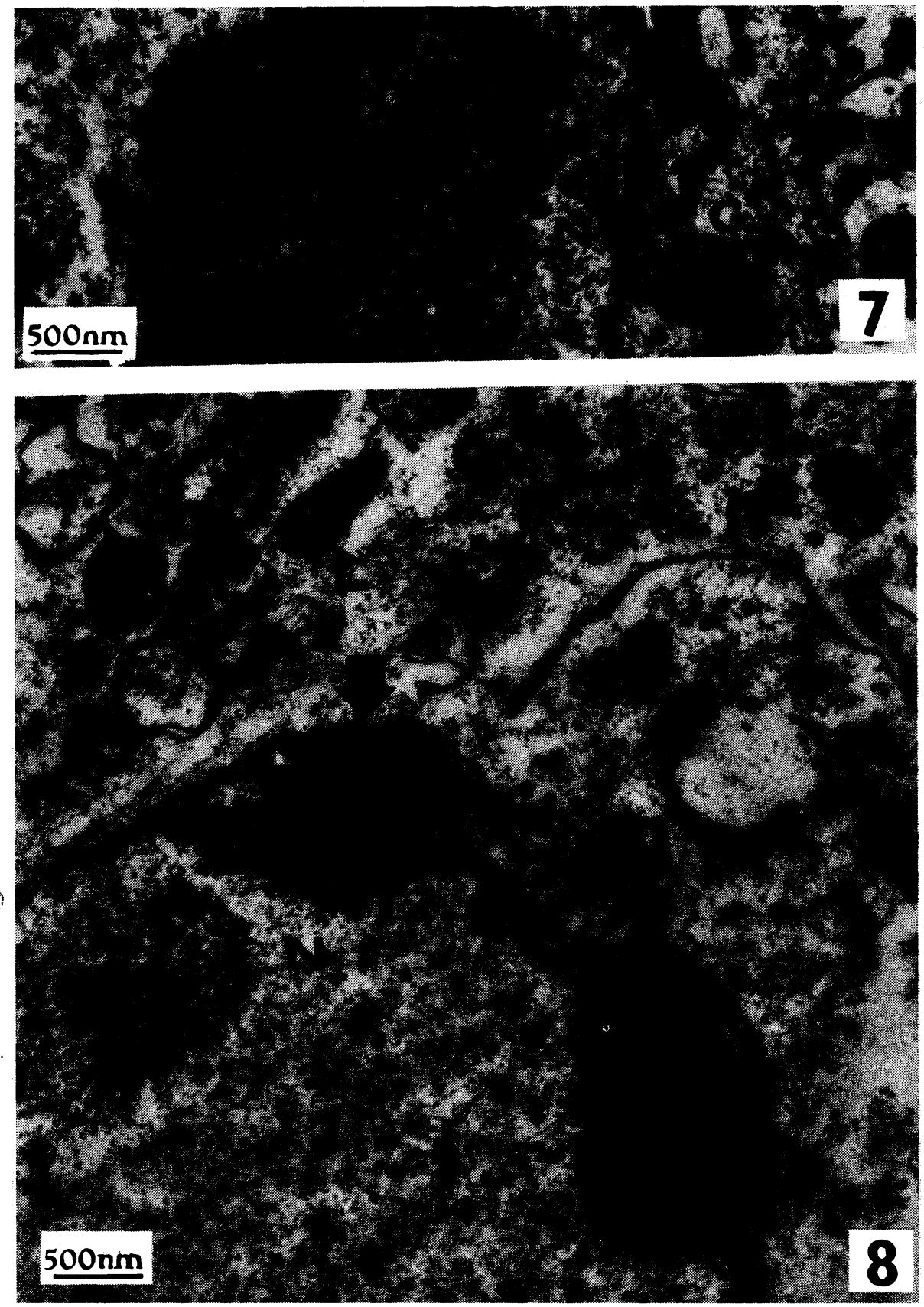

Fig. 7

Nucleocapsid arranged in crystal array in the nucleus (N) of varying core density (PLM 16 hours after infection).

Fig. 8

Reduplication of the nuclear membrane ( 2 arrows) with partial lysis (thick arrow) which facilitates release of nucleocapsids into the cytoplasm (asterisk) (PLM 16 hours after infection). 

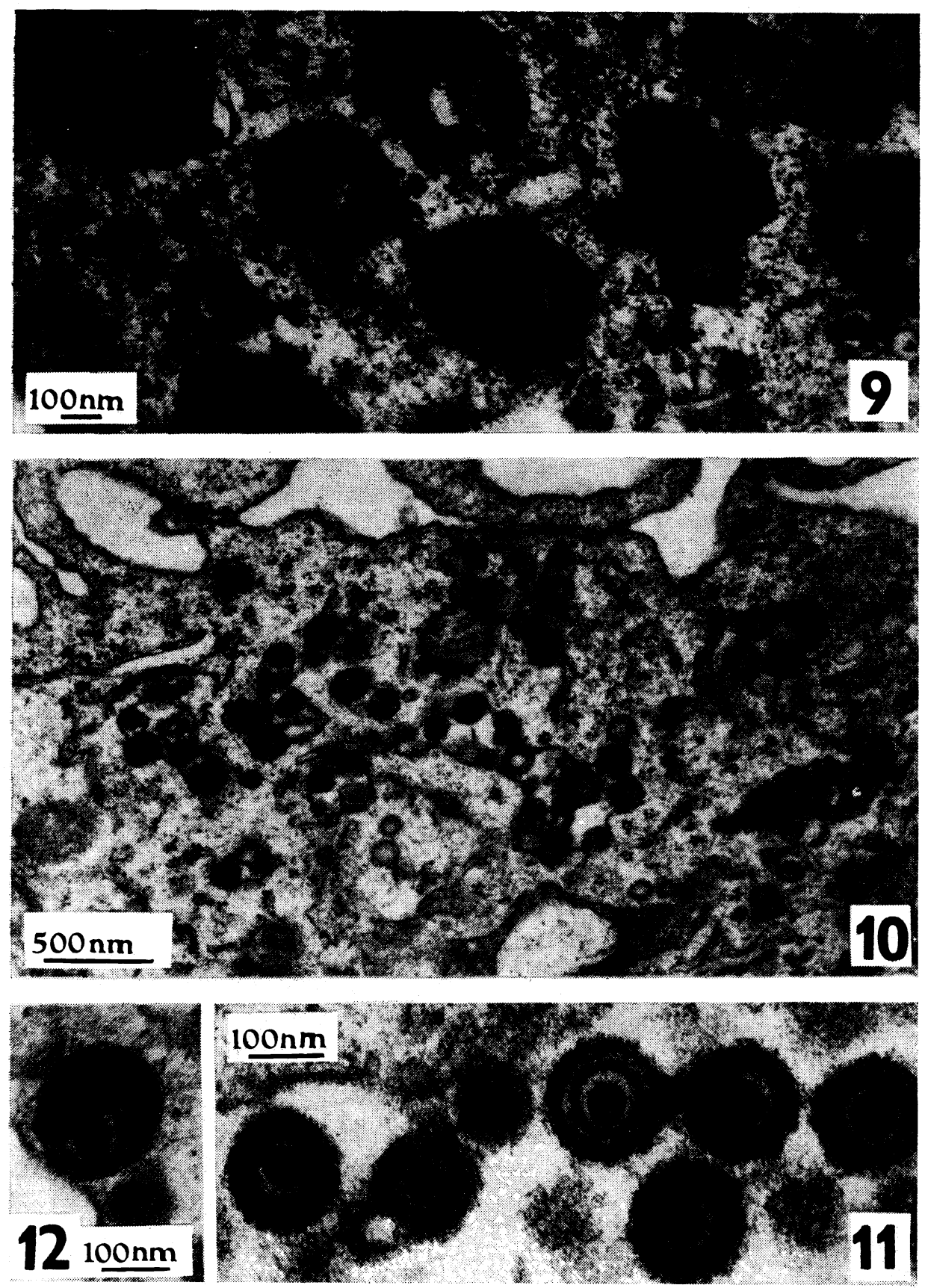

$r$

Fig. 9

Viral particles in lysosomes showing various stages of destruction (PLM 16 hours after infection). Fig. 10

Virions in smooth-membraned tubules (PLM 16 hours after infection). Fig. 11

Virions in the extracellular space (PLM 21 hours after infection).

Fig. 12

Virion with an excentrically-placed nucleocapsid and a large amount of electron dense material between the nucleocapsid and the envelope (PLM 16 hours after infection). 
of the envelope with surface projections. (Fig. 11.) Only few virions in the extracellular space had an excentrically-placed nucleocapsid with a large amount of electron dense material between the nucleocapsid and the envelope (Fig. 12).

\section{Discussion}

The culture of PLM was obtained by the method described for isolation of porcine cytomegalovirus (Watt et al. 1973) and verified in our laboratory (Š míd et al. 1976). The advantages of this approach is the ability of PLM to adhere readily to glass and their distinct morphological features in ultrathin sections (Fruth et al. 1972), which makes them easy to obtain and identify.

Replication of the employed strain of ADV in PLM was demonstrated on the basis of morphogenetic changes in infected cells. The morphogenesis of ADV in PLM was basically similar to that found in pig kidney cell cultures (Felluga 1963; McCracken and Clarke 1971), although some differences were observed. The main of them was the presence of lysis in some cells 2 hours after infection (see Fig. 2), which prevented their identification. In our view such an extensive destruction of cells shortly after infection can occur only in mature phagocytizing cells of intense enzymic activity as is the case with alveolar macrophages (Carr 1973). A certain peculiarity is the finding of virions containing a large amount of electron dense material between the nucleocapsid and the virion (see Fig. 12). Such forms have not yet been described in ADV, but are known to occur, with some differences in the location of electron dense material in the virion, in some other herpesviruses (Chia and Savan 1974; Cook and Stevens 1968; Graighead et al. 1972, a. o.). Moreover, this material may be of varying origin: it may be lysosomal in origin (Gersken et al. 1973) or a structural viral component ( $\mathrm{Nii}$ et al. 1973) or a host cell material acquired by the virus on passage into cytoplasmic tubules (Fong et al. 1973) or virus-specific antibody (Stackpole 1969). Although we can provide no evidence as to the origin of the large amount of electron dense material between the nucleocapsid and the envelope, we are of the opinion that it arises accidentally on acquisition of a large amount of virus-specific material.

In the present study we used PLM from piglets killed at 14, 23 and 45 days of age and demonstrated the ability of ADV to replicate in these cells. The question still remains whether ADV can replicate also in PLM of older pigs and to what extent its replication in PLM is influenced by cellular and humoral immunity. These questions warrant further study.

\section{Morfogeneze viru Aujeszkyho choroby $\mathbf{v}$ buněčných kulturách prasečích plicních makrofágů}

Virulentní kmen viru Aujeszkyho choroby replikoval in vitro $\mathrm{v}$ prasečích plicních makrofázích (PPM) z bezkolostrálních selat starých 14,23 a 45 dní. Za 4 hodiny po infekci $5 \mathrm{PFU} /$ buňku se objevovaly $\mathrm{v}$ jádře dřeni podobné částice, za 8 hodin nukleokapsidy. Viriony se prokazovaly ojediněle $\mathrm{v}$ extracelulárním prostoru od desáté hodiny po infekci. $\mathrm{V}$ pozdějších stadiích infekce se $\mathrm{v}$ jádře nacházelo velké množství nukleokapsid často krystalicky uspořádaných a $\mathrm{v}$ cytoplazmě velké množství virionů jak v kanálcích hlaḍkého endoplazmatického re- 
tikula, tak i v lysozomech. $\mathrm{V}$ tomto období se objevovalo velké množství virionů i v extracelulárním prostoru a výjimečně viriony $s$ větším množstvím elektronově tmavé masy mezi nukleokapsidou a obalem.

\section{Морфогенез вируса болезни Ауески в культурах клеток легочных макрофагов поросят}

Болезнетворный штамм вируса болезни Ауески развивали в лабораторных условиях в легочных макрофагах (РPM) поросят без приема молозива в возрасте 14,23 и 45 дней. В течение 4 часов после инфекции 5 РРЦ/клетку в ядре появлялись нуклеокапсидам похожие частицы, через 8 часов - нуклеокапсиды. В единичных случаях вирионы были установлены в экстрацеллюлярном пространстве с десятого часа после инфекпии. На более поздних страдиях инфекции в ядре находилось большое количество нуклеокапсидов, расположенных зачастую кристаллически, и в цитопазме - большое количество вирионов не только в канальцах гладкого эндоплазматического ретикулума, но и в лисозомах. Большое количество вирионов было в данный период установлено также в экстрацеллюлярном пространстве, в исключительном случае вирионы с большим количеством электронно темной массы выявлялись между нуклеокапсидой и оболочкой.

\section{References}

BASKERVILLE, A.: Ultrastructural changes in the pulmonary airways of pigs infected with a strain of Aujeszky's disease virus. Res. vet. Sci., 13, 1972: 127-132.

BASKERVILLE, A. - McFERRAN, J. B. - DOW, C.: Aujeszký's disease in pigs. Vet. Bull., 43, 1973: $465-480$.

CARR, I.: The macrophages. A review of ultrastructure and function. Academic Press, LondonNew York 1973, p. 154.

CHIA, W. K. - SAVAN, M.: Electron microscopic observations on infectious bovine rhinotracheitis virus in bovine fetal tracheal organ cultures. Arch. ges. Virusforsch., 45, 1974: 185 to 198 .

COOK, M. L. - STEVENS, J. G.: Labile coat: Reason for noninfectious cell-free varicella-zoster virus in culture. J. Virol., 2, 1968: 1458-1464.

CRAIGHEAD, J. E. - KANICH, R. E. - ALMEIDA, J. D.: Nonviral microbodies with viral antigenicity produced in cytomegalovirus-infected cells. J. Virol., 10, 1972: 766-775.

EDINGTON, N. - PLOWRIGHT, W. - WATT, R. G.: Generalized porcine cytomegalic inclusion disease: Distribution of cytomegalic cells and virus. J. comp. Path., 86, 1976: 191-202.

FELLUGA, B.: Electron microscopic observations on pseudorabies virus development in a line of pig kidney cells. Annali Sclavo, 5, 1963: 412-424.

FONG, C. K. Y. - TENSER, R. B. - HSIUNG, G. D. - GROSS, P. A.: Ultrastructural studies on the envelopment and release of guinea pig herpeslike virus in cultured cells. Virology, 52, 1973: 468-477.

FURTH, R. van - COHN, Z. A. - HIRSCH, J. G. - HUMPHREY, J. H. - SPECTOR,

W. G. - LANGEVOORT, H. L.: The mononuclear phagocyte system: a new classification of macrophages, monocytes, and their precursor cells. Bull. Wld. Hlth. Org., 46, 1972: 845 to 852 .

GERSHON, A. - COSIO, L. - BRUNELL, P. A.: Observation on the growth of varicella zoster virus in human diploid cells. J. gen. Virol., 18, 1973: 21-31.

HOLUB, A.: Semisyntetická vysokokalorická dieta pro selata uměle odchovaná od druhého dne života. Vet. Med., Praha, 8, 1963: 427-430.

JOHNSON, R. T:: The pathogenesis of herpes virus encephalitis. II. A cellular basis for the development of resistance with age. J. Exp. Med., 12, 1964: 359-374.

McCRACKEN, R. M. - CLARKE, J. K.: A thin-section of the morphogenesis of Aujeszky's disease virus in synchronously infected cell cultures. Arch. ges. Virusforsch., 34, 1971: 189-201. 
MIMS, C. A.: Factors in the mechanism of persistence of viral infections. Progr. med. Virol., 18, 1974: 1-14.

MOGENSEN, S. C.: Role of macrophages in natural resistance to virus infections. Microbiol. Rev., 43, 1979: 1-26.

SABÓ, A. - RAJČ́NI, J.: Latent pseudorabies virus infection in pigs. Acta virol., 20, 1976: $208-214$.

SILVERSTEIN, S.: Macrophages and viral immunity. Sem. haemat., 7, 185-214.

SMIID, B. - VALÍCEK, L. - MENŠ́K, J.: Získávání prasečích plicních makrofágů pro kultivaci prasečího cytomegaloviru. Vet. Med., Praha, 21, 1976: 589-595.

STACKPOLE, C. W.: Herpes - type virus of the renal adenocarcinoma. J. Virol., 4, 1969: $75-93$.

STEVENS, J. G. - COOK, M. L.: Restriction of herpes simplex virus by macrophages. An analysis of the cell-virus interaction. J. Exp. Med., 133, 1971: 19-38.

VALÍCEK, L. - SMÍD, B.: Electron microscopy of porcine cytomegalovirus in pig lung macrophage cultures. Zbl. Vet. Med. B, 26, 1979: 371-381.

WATT, R. G. - PLOWRIGHT, W. - SABÓ, A. - EDINGTON, N.: A sensitive cell culture system for the virus porcine inclusion body rhinitis (cytomegalic inclusion disease). Res. vet. Sci., 14, 1973: 119-121. 